\title{
FEATURES OF THE CHINESE RIVER CRUISES AND PASSENGER SHIPS SERVING THESE CRUISE LINES
}

\author{
ОСОБЛИВОСТІ КІТАЙСЬКИХ РІЧКОВИХ КРУЇЗІВ \\ І ПАСАЖИРСЬКИХ СУДЕН, ЩО ОБСЛУГОВУЮТЬ ЦІ КРУЇЗНІ ЛІНІї
}

\author{
Oleksandr H. Yehorov \\ egorovag@meb.com.ua \\ ORCID: 0000-0002-2050-8640
}

\author{
О. Г. Сгоров, \\ канд. техн. наук, \\ старший науковий співробітник \\ Marine Engineering Bureau, Odesa
Морське інженерне бюро, м. Одеса
}

\begin{abstract}
Purpose. Analysis of the Chinese river fleet and cruises. Methodology. Methods of ship theory and design, analysis and statistics are applied. Results. Features of the Chinese river cruises are highlighted, main cruise companies are identified, design and construction requirements for river cruise passenger ships (RCPS) are analyzed. Scientific novelty. For the first time, complex study of the China modern river cruise passenger fleet was carried out. Practical impact. Analysis of passenger transportation by water transport in China is carried out. By 2030 the Chinese cruise market (sea and river) is expected to become the largest in the world - 8-10 million passengers. As on 201934 international-level RCPS with passenger capacity of 10.406 people, as well as 18 standard RSPS (for local tourists) with passenger capacity of 4.498 people were operated on the Yangtze River. Star rating for Chinese RCPS is assigned in accordance with the National Standard GB/T 15731-2015. In fact, $5 *$ in meaning of GB/T 15731-2015 Standard is not a European $5^{*}$, therefore many leading cruise companies pay special attention to global trends in luxury segment river cruises at the stage of design new ships and creation of concept. River cruise ships in China are built under the supervision of ZC inspection body of Maritime Safety Administration in accordance with the Guidelines for compulsory certification of inland navigation vessels. At the same time, there is no need to approve the project and obtain CCS (China classification society) approval. Navigation area and permitted area with fast currents are assigned when river vessel is surveyed under the supervision of ZC. CCS has developed Rules to add additional symbols to cruise ship class. They apply only to sea cruise and cargo-passenger ships, but approach is quite modern, which combines safety, comfort and star rating of cruises with design. Approaches to design of river cruise passenger ships in China can be used in native design practice.
\end{abstract}

Key words: China; river passenger ship; cruise; innovation; classification; design.

Анотація. Мета. Аналіз китайського річкового флоту і круїзів. Методика. Застосовано методи теорії і проектування корабля, аналізу і статистики. Результати. Виділено особливості китайських річкових круїзів, визначено основні круїзні компанії, проаналізовано вимоги до проектування і будівництва річкових круїзних пасажирських суден (РКПС). Наукова новизна. Вперше виконано комплексне дослідження сучасного річкового круїзного пасажирського флоту КНР. Практичне значення. Виконано аналіз пасажирських перевезень водним транспортом в КНР. До 2030 року очікується, що китайський ринок круїзів (морський і річковий) стане найбільшим в світі - 8-10 млн. пасажирів. В 2019 на річці Янцзи працювало 34 РКПС міжнародного рівня пасажиромісткістю 10406 чоловік, а також 18 РКПС стандартного (для місцевих туристів) рівня пасажиромісткістю 4498 чоловік. Зірковість на китайських РКПС призначається відповідно до Національного Стандарту GB/T 15731-2015. Фактично 5* в розумінні Стандарту GB/T 15731-2015 - це не європейські 5*, тому багато провідних круїзних компаній ще на етапі проектування нових суден і створення дизайн-проекту приділяють особливу увагу світовим тенденціям в річкових круїзах люксового сегменту. Річкові круїзні судна в Китаї будуються під наглядом інспекційного органу ZC Управління з безпеки мореплавства відповідно до Керівництва про обов'язкове інспектування суден внутрішнього плавання. При цьому немає необхідності узгоджувати проект і отримувати схвалення CCS (Китайського класифікаційного суспільства). При інспектуванні річкового судна під наглядом ZC призначається район плавання і дозволена ділянка зі швидкими течіями. CCS розроблено Правила для внесення в клас круїзних суден додаткових символів. Поширюються вони тільки на морські круїзні і вантажопасажирські судна, але підхід досить сучасний, який погоджує безпеку, комфортабельність i зірковість круїзів з проектуванням. Підходи до проектування річкових круїзних пасажирських суден у Китаї можуть бути використані у вітчизняній практиці проектування.

Ключові слова: Китай; річкове пасажирське судно; круїз; інновація; класифікація; проектування. 


\section{ПОСТАНОВКА ЗАДАЧІ}

Круїзи на річкових суднах в усіх країнах світу стають популярнішими з кожним роком. Розширюється географія круїзів, змінюються підходи до надання послуг на борту, модернізуються і будуються нові річкові круїзні пасажирські судна (РКПС) $[1,2]$. Круїзи по внутрішніх водних шляхах (ВВШ) КНР, поряд 3 європейськими, російськими, нільськими, американськими і азіатськими (річка Меконг) круїзами, привертають велику кількість як «в'їзних», так і місцевих туристів. У XXI столітті, особливо в другому десятилітті, відбулася зміна підходів до проектування таких суден - від копіювання європейських до створення власних оригінальних рішень.

\section{АНАЛІЗ ОСТАННІХ ДОСЛІДЖЕНЬ І ПУБЛІКАЦИЙ}

У літературі відсутні системні дослідження досвіду проектування, будівництва та експлуатації річкових круїзних пасажирських суден Китаю.

Метою дослідження $\epsilon$ вивчення флоту китайських РКПС і особливостей круїзів, визначення та аналіз застосовуваних технічних рішень, з метою використання при проектуванні нових РКПС для ВВШ в європейських країнах.

\section{МЕТОДИ, ОБ'СКТ ТА ПРЕДМЕТ ДОСЛІДЖЕННЯ}

Застосовувалися методи теорії і проектування корабля, аналізу і статистики. Об'єкт - річкові круїзні пасажирські судна. Предмет - характеристики річкових круїзних пасажирських суден.

\section{ОСНОВНИЙ МАТЕРІАЛ}

Масштабне судноплавство на ВВШ Китаю має довгу історію, починаючи ще 3 давніх часів. Китайські імператори використовували джонки як для пересування по річці, так і в морі [3]. Перше 17-метрове парове вантажне судно на річці Янцзи «Lichuan» було побудовано в Шанхаї британським бізнесменом Рідом в 1898 році [4]. Першим річковим круїзним судном на річці Янцзи вважається судно «Kunlun», яке було зафрахтоване в 1979 році спеціально для круїзу до трьох ущелин. Активно річкові круїзи почали розвиватися з 1983 року. Основними пасажирами були переважно китайські туристи [3]. Зараз, після завершення будівництва гідровузла «Три ущелини», річка Янцзи привертає все більшу кількість іноземних туристів, в основному пенсіонерів - до $90 \%$.

За даними на 2018 рік, на ВВШ КНР працювало 17651 пасажирське судно загальною пасажиромісткістю 715,9 тис. чол. [5]. У цю кількість входили i круїзні пасажирські судна, i прогулянкові, i судна для лінійних перевезень. У 2017 році середній вік пасажирського флоту становив 10,6 років [6]. У 2018 року пасажиропотік склав 279,8 млн. чол. [7].
У 2019 водним транспортом КНР було перевезено 272,7 млн. чол., пасажирообіг - 8,022 млрд. чол.-км., загальна пасажиромісткість всіх типів пасажирських суден склала 885,8 тис. чол., при цьому кількість лінійних пасажирських поромів продовжила скорочуватися - 224 порома, якими перевезено 73 млн. чол. (в 2015 році, наприклад, таких поромів було 310) [8].

До 2030 року очікується, що китайський ринок круїзів (морський i річковий) стане найбільшим в світі - 8-10 млн. пасажирів. За даними Міжнародної асоціації круїзних ліній (Cruise Lines International Association) за 2018 рік, Китай є лідером в круїзному сегменті Азії з 4,24 млн. пасажирами, 70\% усього пасажиропотоку регіону [9].

На 2019 рік протяжність судноплавних водних шляхів в Китаї - 127300 км, з них з гарантованими габаритами суднових ходів - 66700 км (див. рисунок 1). Основними зарегульованими внутрішніми водними шляхами є: річка Янцзи - 64825 км судноплавний шляхів, Перлова річка - 16495 км, річка Хейлунцзян (Амур) - 8211 км, Великий Китайський канал Пекін-Ханчжоу - 1438 км; річка Хуанхе 3533 км [8].

Практично третина від усього пасажиропотоку припадає на річкові порти: Чунцин (річка Янцзи, 6,86 млн. чол.), Ічан (річка Янцзи, 1,8 млн. чол.), Фошань (річка Перлова, 570 тис. чол.) та інші [5].

Особливе значення мають порти Чунцин і Ічан на річці Янцзи як основні китайські річкові круїзні порти (див. рисунок 2), щорічно, починаючи з відкриття греблі гідровузла «Три ущелини», більше 400000 пасажирів подорожує в круїзах між Чунцином і Ічаном [11]. У 2017 році круїзний пасажиропотік на річці Янцзи виріс до 560000 чоловік. Круїзи виконуються з березня по грудень.

Крім лінії Чунцин - Ічан по річці Янцзи відбуваються круїзи по більш довгому маршруту Чунцин Шанхай, раніше були круїзи Чунцин - Ухань. Якщо перший маршрут займає 4 дні (за течією) і 5 днів (проти течії), довжина маршруту 648 км, то другий триває 15 днів, довжина маршруту 2644 км (див. рисунок 3). Виконуються також одноденні круїзи гідровузлом «Три ущелини», навколо Чунцина і Ічана [12].

Річкові круїзи, в класичному їх розумінні, на інших китайських річках не особливо поширені. Більшість круїзів - одноденні або прогулянкові тури на кілька годин і $є$ частиною великих екскурсійних турів. Найбільш популярною серед таких поїздок $\epsilon$ круїз по річці Лі (Гуйцзян) з Гуйліня в Яншо (протяжність маршруту 83 км, в середньому круїз триває 4 години по течії, в зворотному напрямку круїзи не виконуються, див. рисунок 4) [13]. Одноденні круїзи по річці Лі здійснюються на прогулянкових суднах рівня 3-4,5 зірки (різниця в комфортабельності, кількості пасажирів на борту), а також на бамбукових плотах [14]. 


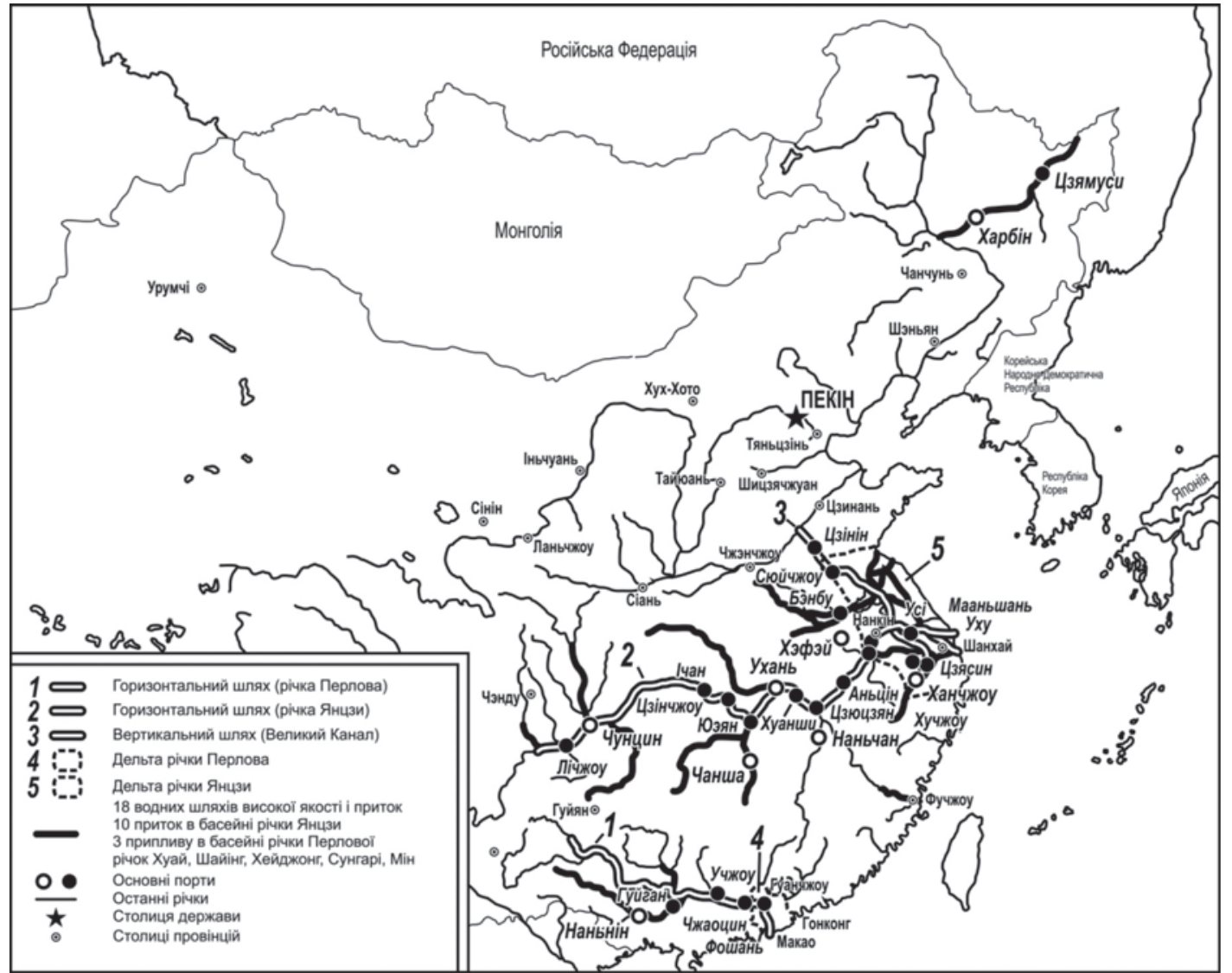

Рис. 1. Карта внутрішніх водних шляхів КНР

Джерело: [5]

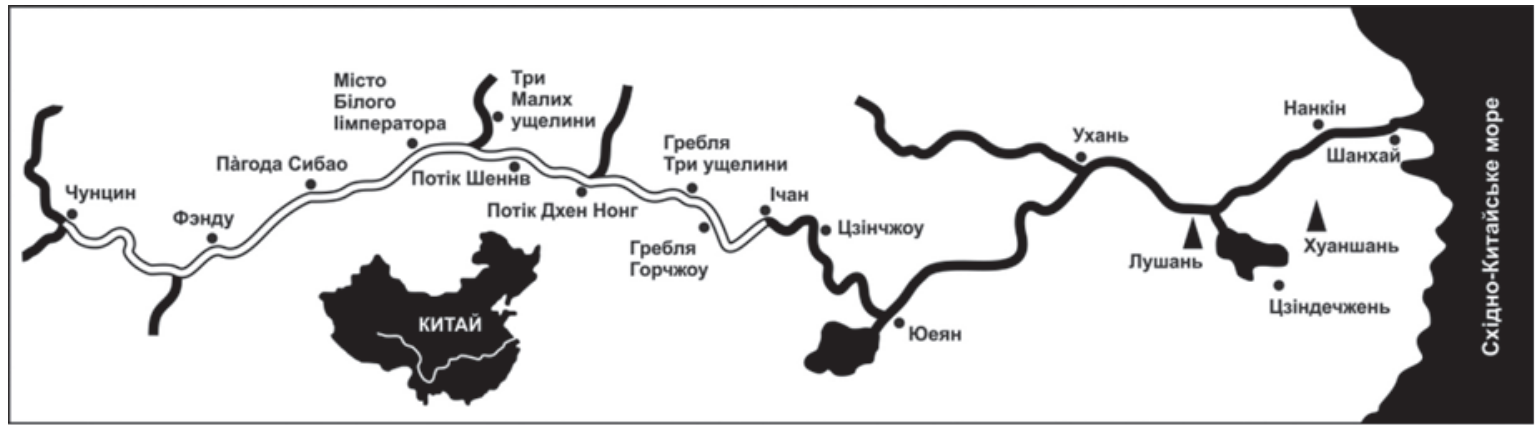

Рис. 2. Найбільш популярна річкова круїзна лінія в КНР Чунцин - Ічан Джерело: [10]

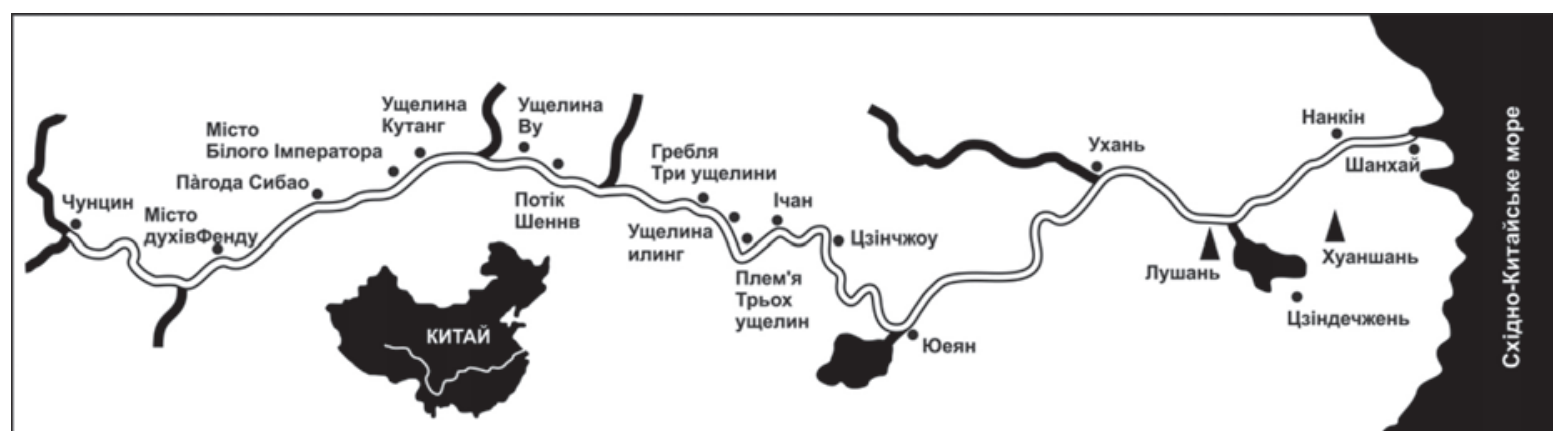

Рис. 3. Річкова круїзна лінія Чунцин - Шанхай Джерело: [12] 
Загальний вигляд типового круїзного судна для одноденних прогулянок по річці Лі наведено на рисунку 5.

Не менш популярними є водні прогулянки по річці Хуанпу в Шанхаї (див. рисунок 6), по річці Перлова в Гуанчжоу, по озеру Сіху в Ханчжоу (саме південне місто Великого Китайського Каналу), а також по самому Великому Каналу (Сучжоу, Чанчжоу, Янчжоу - основні міста) [13].
Китай планує розширювати географію річкових круїзів, наприклад, опрацьовується маршрут по річці Перлова від Гонконгу через провінцію Гуандун (місто Гуанчжоу), Учжоу до Гуйган і Наньнін (див. рисунок 7), по річках Фучунь, Цяньтан і Сіньань 3 Ханчжоу [15].

У період з 1987 по 2003 рр. на ВВШ КНР скоротилася складова лінійних пасажирських перевезень через масове будівництво мостів і, відповідно,

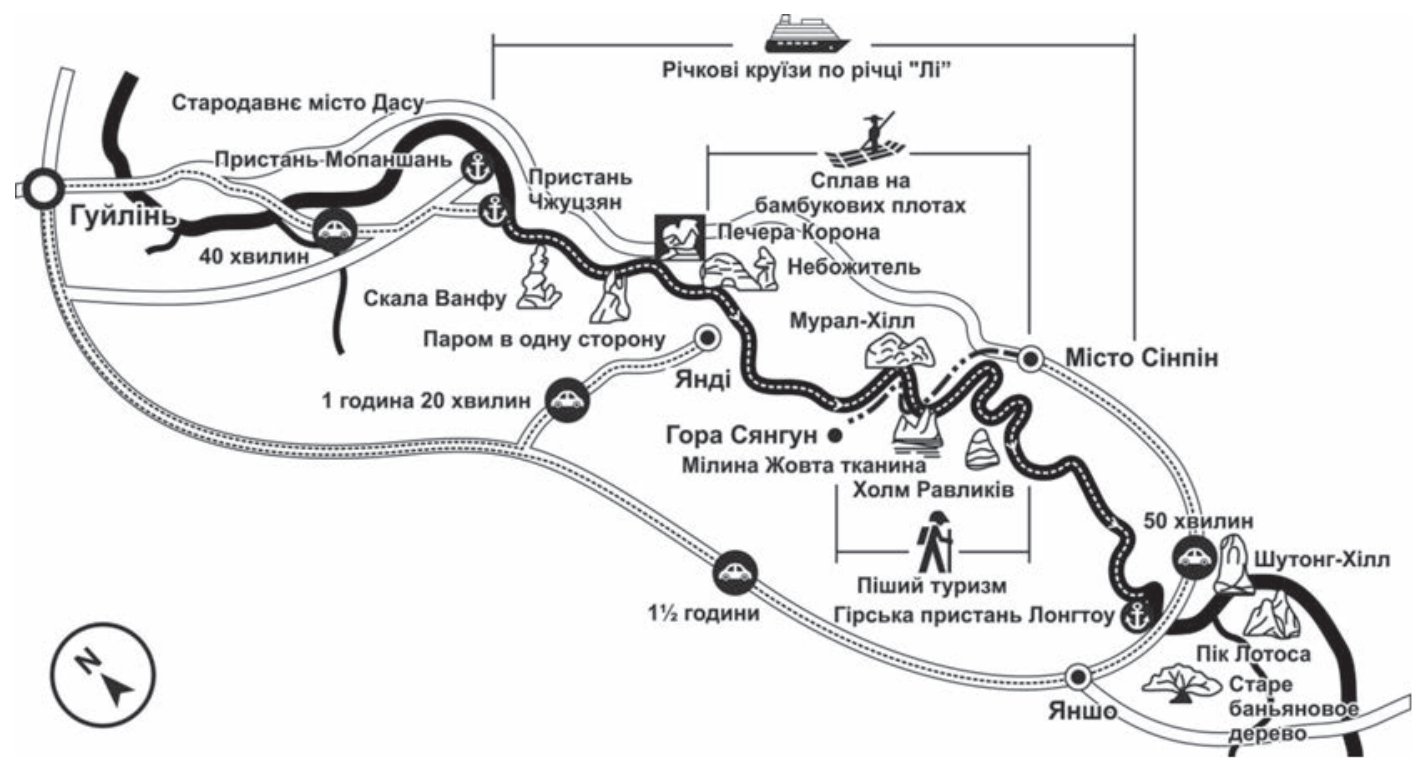

Рис. 4. Одноденний круїз по річці Лі

Джерело: [14]

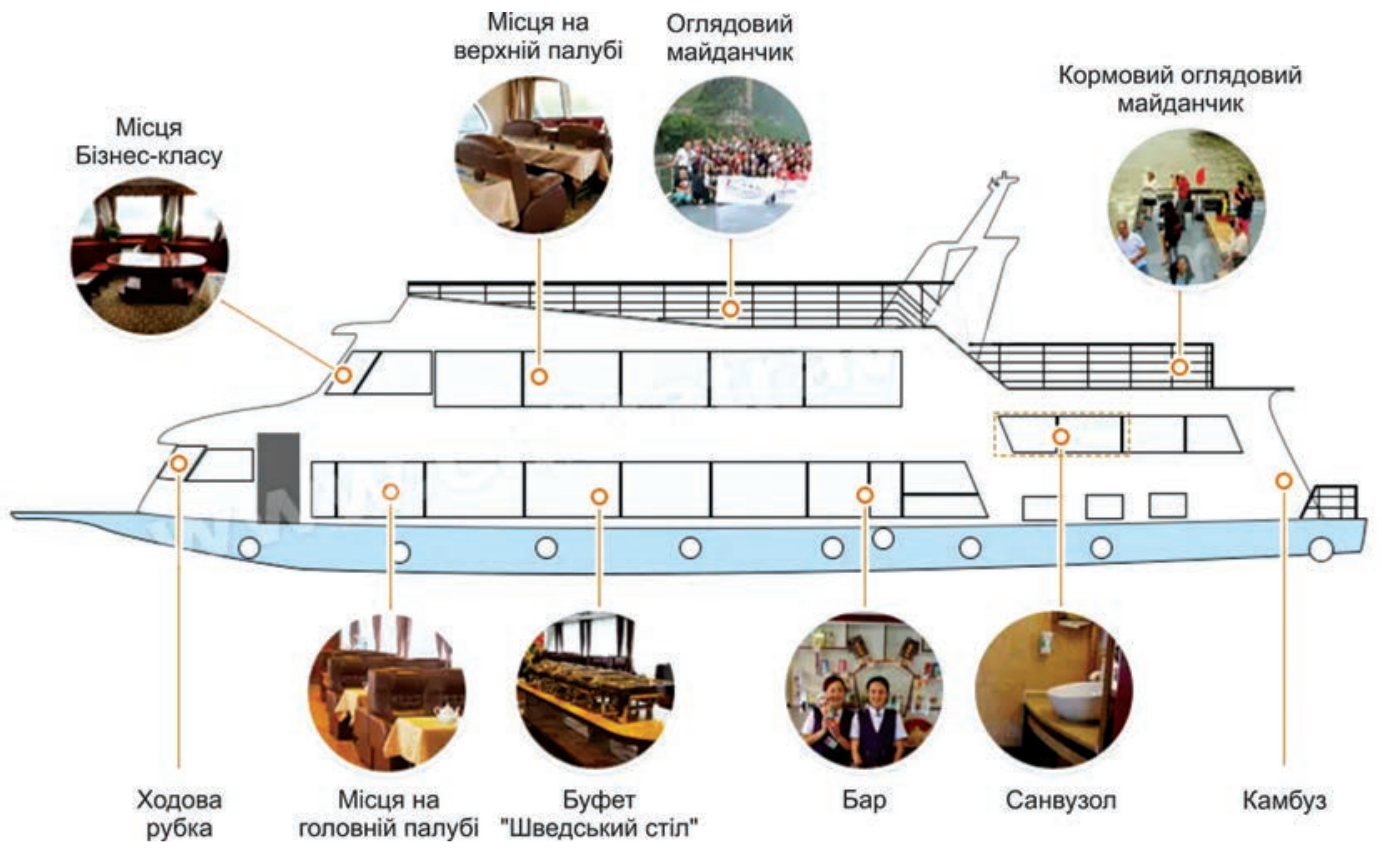

Рис. 5. Типове круїзне судно для одноденних прогулянок по річці Лі

Джерело: [14] 


\section{СУДНОБУДУВАННЯ № 1 2021}

динамічне вибуття вантажопасажирських і пасажирських поромів. У той же період значно знизився пасажиропотік на річці Янцзи через будівництво і введення в експлуатацію залізничних ліній вздовж річки [5].

Починаючи з 2004 року пасажиропотік на річках Китаю почав зростати за рахунок розвитку річкових круїзів і залучення «в”ізних» туристів [5], що цілком відповідає загальносвітовим трендам річкових круїзів, наприклад, більше $60 \%$ всього річкового круїзного флоту Європи побудовано вже в XXI столітті [1]. В першу чергу, зростанню сприяло будівництво гідровузла «Три ущелини» на річці Янцзи і прийняття в рамках XI п'ятирічного плану розвитку економіки КНР (2006-2010) рішення про підтримку і розвиток річкового круїзного судноплавства [5]. Міністерство транспорту випустило «Національний план стандартизації річкових суден», в якому були вказані цільові показники на 2010 і 2020 роки. 32009 по 2013 роки Китай приступив до уніфікації річкових суден на річці Янцзи, включаючи РКПС, були виділені кошти на модернізацію систем обробки стічних вод на існуючих РКПС [5]. Як підсумок, зараз в експлуатації немає жодного РКПС на річці Янцзи для «в'їзних» туристів, побудованого в минулому столітті - вони все списані, включаючи 3 РКПС 302 проекту 1991 року побудови, які спочатку будувалися для російських ВВШ, або перебудовані [16]. Всі нові судна відповідають сучасним вимогам по екологічності, економічності і комфортабельності. Розмірення і осадка нових РКПС вибираються з урахуванням запущеного в експлуатацію гідровузла «Три ущелини».

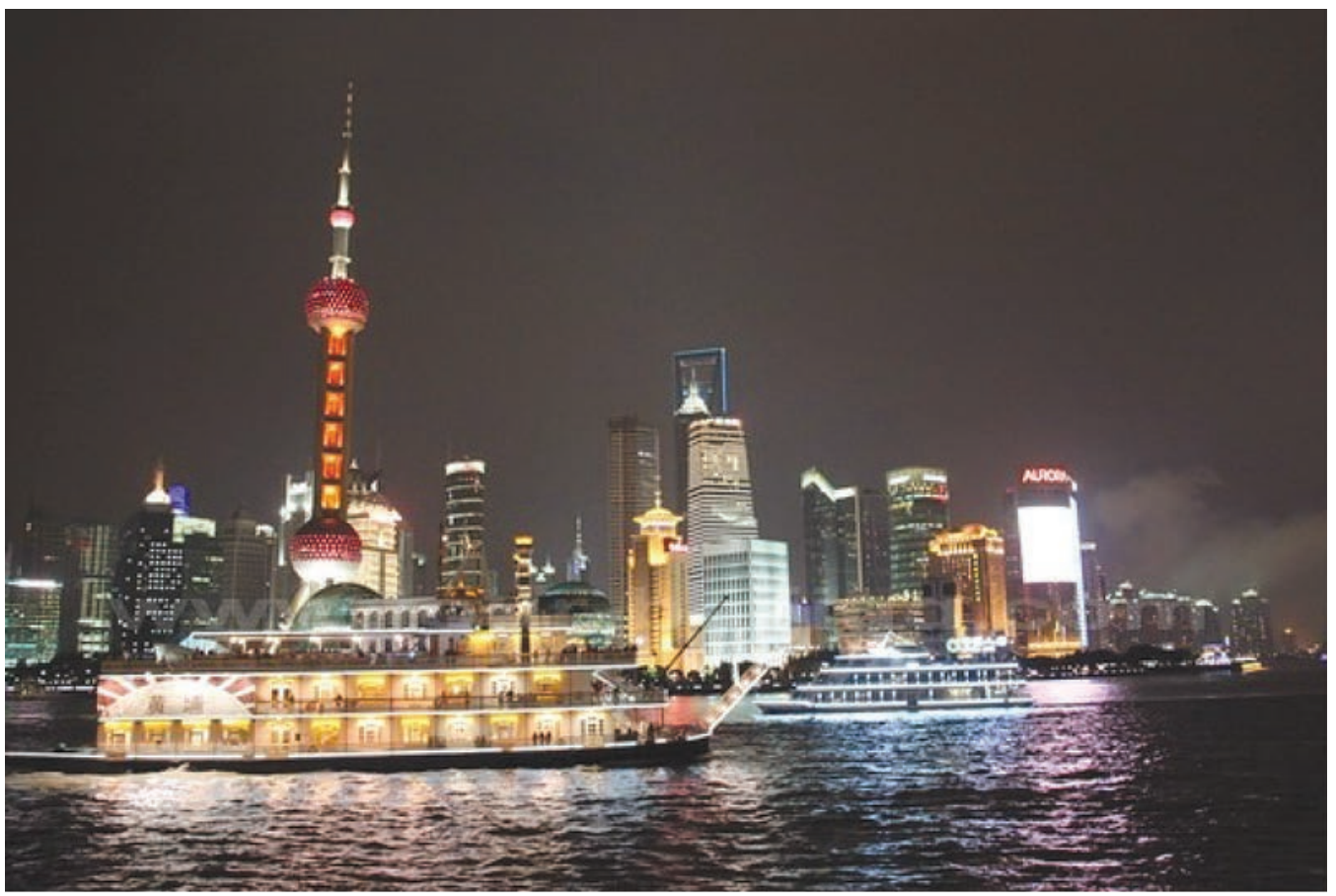

Рис. 6. Прогулянкові судна на річці Хуанпу, Шанхай Джерело: [13]

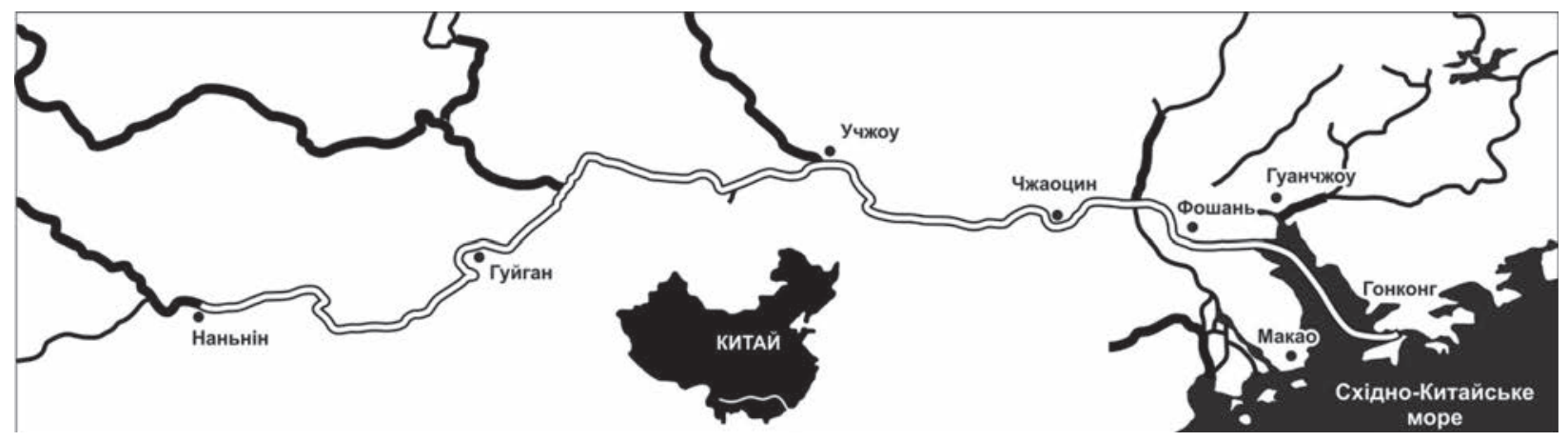

Рис. 7. Перспективний маршрут на річці Перлова

Джерело: [5] 
Звичайно, були кризові періоди - 2012-2013 роки та 2015-2016 роки, коли річкові круїзи зазнавали труднощів 3 тих чи інших причин.

2012-2013 роки - надлишок річкового круїзного флоту, який спричинив за собою різке, до 50\%, падіння цін на річкові круїзи. У період з 2009 по 2013 роки було побудовано 16 нових РКПС великої місткості для річки Янцзи. I це на додаток до 90 прогулянкових і круїзних суден і 200 швидкісних пасажирських катерів, які працювали на той час. Крім того, швидкий перехід від лінійних пасажирських сервісів до круїзних позначився на якості послуг, що надаються, які не дотягували до міжнародного рівня, а також на безпеці самих круїзних суден: більшість суден будувалась без урахування вимог міжнародних конвенцій $[3,11]$.

2015-2016 роки - падіння попиту більш ніж на $30 \%$ на річкові круїзи через трагедію з РКПС «Dong Fang Zhi Xing» («Зірка Сходу») в червні 2015 року на річці Янцзи (див. рисунок 8).

Судно «Зірка Сходу», перебуваючи в рейсі з пасажирами на борту з Нанкіна в Чунцин, практично миттєво, менш ніж за 2 хвилини, перекинулось через сильний вітровий порив. 442 людини загинуло, вдалось врятувати лише 12 [18]. Китайське РКПС «Зірка
Сходу» - класичне сталеве судно, з похилим форштевнем і транцевою кормовою кінцевістю, 3 подвійним дном. Побудовано в Китаї в 1994 році. Габаритна довжина - 76,5 м (62,0 м до розмірної модернізації 1997 року), ширина - 12,4 м, висота борту - 3,1 м, надводний габарит - 18,6 м, осадка - 2,16 м. На момент аварії судно мало всі необхідні сертифікати і знаходилося в дозволеному районі плавання [18].

За результатами офіційного розслідування були посилені вимоги до річкових круїзних пасажирських суден, а також введена заборона на експлуатацію цих суден на ділянці від Шанхая до Ічана [18]. 32015 до 2021 року РКПС працювали виключно на лінії Чунцин - Ічан, в 2021 планується відновити круїзи на лінії Шанхай - Чунцин [12]. У 2016 році було списано майже 50 старих круїзних суден.

Вже в 2017 року попит на річкові круїзи відновився і показував своє зростання, кількість бронювань зросла на 40\%. Значний інтерес серед туристів став з'являтися до РКПС ультра-люксового сегменту, яких на ринку Китаю практично немає, в роботі всього одне судно «Yangzi Explorer» 2008 року будівництва, модернізоване в 2016 році. Результатом цього інтересу стало створення компанії «Star River Cruises», яка

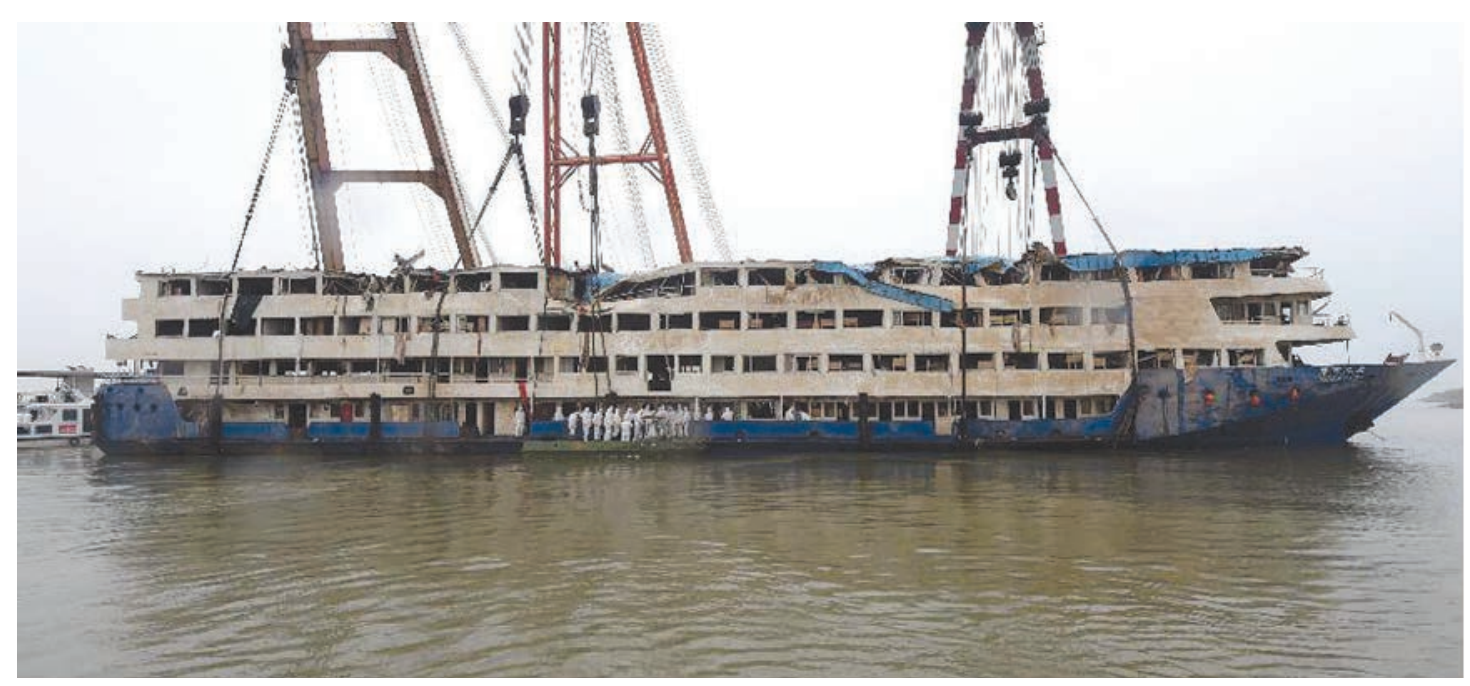

Рис. 8. Підйом затонулого РКПС «Зірка Сходу» Джерело: [17]
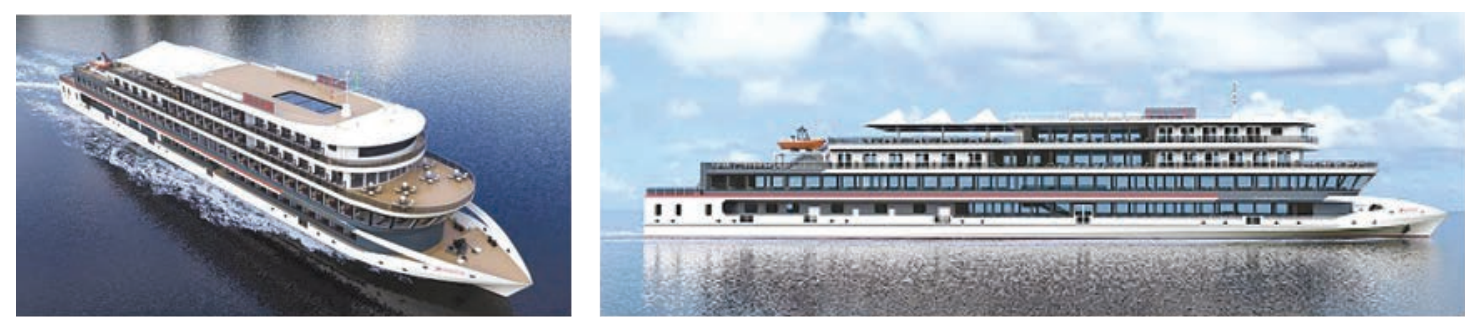

Рис. 9. Загальний вигляд найпотужнішого в світі повністю електричного річкового пасажирського судна «Yangtze River Three Gorges 1» для одноденних круїзів Джерело: [23] 


\section{СУДНОБУДУВАННЯ №1-2021}

планує вийти на місцевий ринок з 2022 року зі своїм флотом [19].

В 2019 на річці Янцзи працювало 34 РКПС міжнародного рівня пасажиромісткістю 10406 чоловік, а також 18 РКПС стандартного (для місцевих туристів) рівня пасажиромісткістю 4498 чоловік [15]. У 2020 році було здано в експлуатацію ще одне РКПС «Victoria Sabrina» американської компанії «Victoria Cruises» пасажиромісткістю 572 чоловіка.

Коронавірусна хвороба Covid-19 вплинула на річкові круїзи по річці Янцзи в 2020 році, враховуючи, що Ухань знаходиться в безпосередній близькості до основного туристичного маршруту Чунцин - Ічан, 7 РКПС стандартного рівня було направлено в Ухань в якості плавготелей для лікарів [20,21]. Всі круїзи було скасовано, повноцінне відновлення очікується вже в 2021 році, розроблено рекомендації щодо попередження поширення інфекції на борту круїзних суден [22].

Основними круїзними компаніями, які обслуговують, в тому числі, «в 'їзних» туристів на річці Янцзи і оперують РКПС міжнародного рівня, є: «Century Cruises», «Changjiang Cruises», «China Goddess Cruises», «President Cruises», «Victoria Cruises», «Yangtze Gold Cruises», «Sanctuary Yangzi Explorer» [16].

Окремо варто відзначити будівництво найпотужнішого в світі повністю електричного річкового пасажирського судна «Yangtze River Three Gorges 1» для одноденних круїзів в районі гідровузла «Три ущелини», включаючи можливість підйому / спуску на суднопідіймачі (загальний вигляд див. рисунок 9) [23].

Судно планується здати в експлуатацію восени 2021 року. На «Yangtze River Three Gorges 1» встановлені акумуляторні батареї китайської компанії CATL
(Contemporary Amperex Technology Co., Limited) сумарною потужністю 7,5 МВт.год. В установку входить більше 10000 літій-залізо-фосфатних батарей. Передбачено також температурні датчики, що контролюють перегрів елементів. Джерело заряду акумуляторних батарей - енергія, яка виробляється від роботи гідроелектростанції гідровузла «Три ущелини» [23]. У 2019-2020 роках були здані в експлуатацію прогулянкові судна на батареях CATL: «Marine Cruise 12909» (перше електричне судно на річці Янцзи), «Guanyutai» (на озері Канас, Синьцзян, див. рисунок 10), на Великому Китайському Каналі в Сучжоу, на річці Перлова в Гуанчжоу, для Провінції Фуцзянь, порт Сямень.

Відсутність низьких мостів і ліній електропередач на ділянці Шанхай - Чунцин дозволяє проектувати і будувати китайські РКПС з надводним габаритом більше за 20 м, що значно перевищує аналогічний параметр на російських і європейських РКПС. 3'являються додаткові палуби і площі, які так необхідні для річкових круїзних суден в умовах обмеженої довжини і ширини. Стандартні головні розмірення типових річкових суден для різних ділянок ВВШ КНР прописані в Національному Стандарті GB 38030-2019 [24].

«Зірковість» на китайських РКПС призначається відповідно до Національного Стандарту GB/T 157312015 , це його третя редакція, перша редакція була прийнята в 1995 році, друга - в 2008 році. Всі пасажирські судна, що знаходяться в круїзі більше 24 годин і працюють на ВВШ КНР, повинні відповідати цьому Стандарту. Стандарт регламентує призначення круїзному судну зірок: від 1 до 5 [25]. Всі сучасні китайські

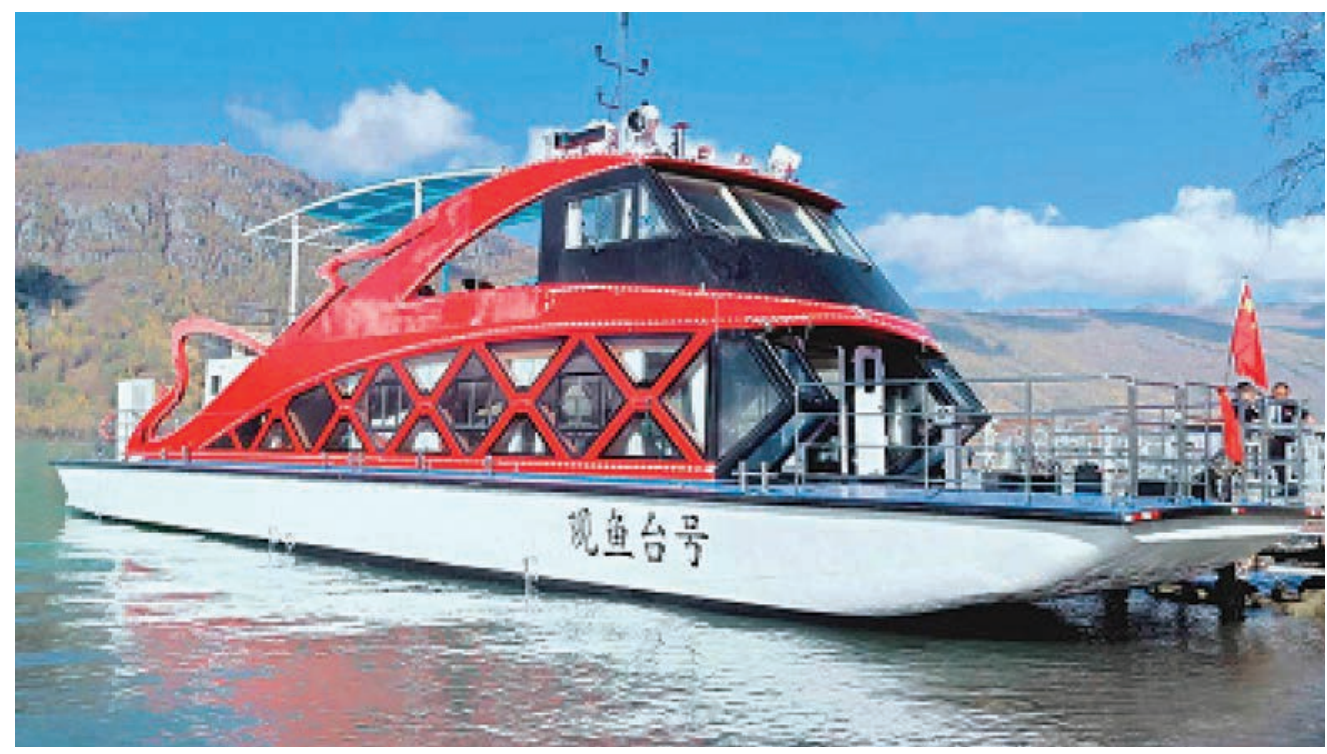

Рис. 10. Загальний вигляд прогулянкового судна «Guanyutai» на озері Канас, що працює на акумуляторних батареях, 2019 року побудови

Джерело: [23] 
РКПС для «в'їзних» туристів виконують вимоги Стандарту на «зірковість» 4 і 5. Але, за фактом, 5* в розумінні Стандарту GB/T 15731-2015 - це не європейські $5^{*}$, тому багато провідних круїзних компаній ще на етапі проектування нових суден і створення дизайн-проекту приділяють особливу увагу світовим тенденціям в річкових круїзах люксового сегменту. Як підсумок - з'являються судна із зірковістю 5+*, які враховують особливості китайського регіону (східні майстер-класи, курси каліграфії, тайцзи і традиційної китайської медицини, окремі віпресторани і лаунж-зони, кімнати для гри в маджонг, китайське караоке KTV, лекції про історію та культуру КНР, китайські елементи в інтер'єрах, тощо).

Річкові круїзні судна в Китаї будуються під наглядом інспекційного органу ZC (Zhongguo Chuanjian) Управління з безпеки море-плавання відповідно до Керівництва про обов'язковий огляд суден внутрішнього плавання [26]. При цьому немає необхідності погоджувати проект і отримувати схвалення китайського класифікаційного суспільства - CCS (China Classification Society). Тільки за бажанням судновласника можливий такий крок, в цьому випадку річкове круїзне судно буде будуватися відповідно до Правил CCS для морських суден [27]. В останні роки інспекційний орган ZC часто наймає CCS для проведення оглядів [28], але в результаті судно все одно отримує Сертифікат огляду, а не класифікаційні документи CCS [29]. При огляді річкового судна під наглядом $\mathrm{ZC}$ призначається район плавання ( $A$ - розрахункова значна висота хвилі $5 \%$ забезпеченості $H s \leq 2,0$ м, $B-0,5$ м $<H s \leq 1,25$ м, $C-H s \leq 0,5$ м) і дозволена ділянка зі швидкими течіями (без дозволу - ділянки зі швидкістю течії $V \leq 3,5 \mathrm{~m} / \mathrm{c}, J_{1}-5,0 \mathrm{~m} / \mathrm{c}<V \leq 6,5 \mathrm{~m} / \mathrm{c}$, $\left.J_{2}-3,5 \mathrm{~m} / \mathrm{c}<V \leq 5,0 \mathrm{~m} / \mathrm{c}\right)$ [26]. Для роботи по річці Янцзи від Шанхая до Чунцину потрібен район плавання А (район В для круїзів між Чунцином і Ічаном) і можливість роботи на швидкісних ділянках $J_{2}$ [18].

Класифікаційне суспільство CCS, що входить в Міжнародну асоціацію класифікаційних суспільств (МАКС), в 2017 році випустило Правила для круїзних суден 3 додатковими символами класу [30]. Поширюються вони тільки на морські круїзні і вантажопасажирські судна, але підхід досить сучасний, який узгоджує безпеку, комфортабельність і зірковість круїзів 3 проектуванням. Для внесення в клас судна символу Cruise, круїзне судно, крім вимог основних Правил CCS $з$ проектування морських суден [27], має відповідати вимогам глав 2 (корпус), 3 (пожежна безпека) i 4 (інші вимоги) Правил для круїзних суден [30].

Для круїзних суден з довжиною понад 90 м повинні бути виконані додаткові розрахунки загальної поздовжньої і місцевої міцності. Конструктивно елементи призначаються з урахуванням результатів цих розрахунків. Для круїзних суден з довжиною понад 150 м повинні також бути виконані прямі розрахунки міцності як всього корпусу судна, так і місцевої міцності, а також розрахунки втомної, граничної і залишкової міцності. У Правилах наведено рекомендовані методики для розрахунків [30].

Розділ з пожежної безпеки Правил для круїзних суден виставляє додаткові до основних Правил [27] вимоги до засобів контролю диму, вентиляційної системи в приміщеннях зі скупченням людей і великих приміщеннях (висота приміщення більше 8 м - атріуми, театри, тощо або площа приміщення більше $500 \mathrm{~m}^{2}$ з висотою більше 3 м - кафе, ресторани, танцювальні майданчики, тощо). Повинен бути виконаний аналіз евакуації з борту судна і розрахунки по безпечному поверненню судна в порт відповідно до вимог MK SOLAS [30].

У 4 розділі Правил для круїзних суден приводяться додаткові вимоги до остійності і морехідності, рятувальних пристроїв, заходів безпеки на борту, пасажиромісткості, вібрації і шуму, мінімального набору приміщень для відпочинку пасажирів, освітлення в різних приміщеннях [30].

Символи класу круїзного судна CEDI $\left(O_{x}, C_{\mathrm{x}}, F_{\mathrm{x}}\right)$ та SEDI (x) визначаються і вносяться в клас на підставі виконання вимог глав 5 і 6 Правил відповідно [30]. CEDI (Cruise Experience Design Index) - конструктивний коефіцієнт якості круїзу; $O_{x}-$ характеристика пасажиромісткості; $C_{\mathrm{x}}$ - характеристика комфортабельності круїзу; $F_{x}$ - характеристика відпочинку пасажира; $\mathrm{x}$ - конструктивна зірковість круїзного судна 3-5* (призначається на етапі проектування); SEDI (Sanitation E(I)nsurance Design Index) - конструктивний санітарний коефіцієнт. Якщо не виконуються умови для конструктивної зірковості $3 *$, то в символі класу ця характеристика не ставиться, наприклад, CEDI $\left(C_{3}, F_{4}\right)[30]$.

Під час призначення характеристики пасажиромісткості $O_{\text {x }}$ визначаються такі параметри, як питома валова місткість (на одного пасажира), мінімальна площа пасажирської каюти, співвідношення кількості пасажирів до екіпажу. Характеристика комфортабельності круїзу $C_{x}$ складається з таких складових частин: максимальний рівень шуму в пасажирських приміщеннях, рівень звукоізоляції в різних приміщеннях, рівень вібрації в різних приміщеннях, температурні режими та їх налаштування в різну погоду, відносна вологість, циркуляція повітря, вентиляція приміщень і повітрообмін. Характеристика відпочинку пасажира $F_{\mathrm{x}}$ враховує різні вимоги до громадських приміщень, ïx склад, структуру і розташування. Вимоги до призначення конструктивного санітарного коефіцієнта SEDI (x) за своєю логікою близькі до вимог Державних санітарних правил [30].

В американському класифікаційному суспільстві ABS (теж член МА-КС), наприклад, $є$ можливість з 2015 року вносити до класу пасажирських суден символи COMF і COMF+, які відображають лише рівень 


\section{СУДНОБУДУВАННЯ №1-2021}

комфортабельності судна, на підставі розрахунків шуму, вібрації, мікроклімату та освітлення [31].

\section{ОБГОВОРЕННЯ ОТРИМАНИХ РЕЗУЛЬТАТІВ І ВИСНОВКИ}

Виконано аналіз пасажирських перевезень водним транспортом КНР. До 2030 року очікується, що китайський ринок круїзів (морський і річковий) стане найбільшим в світі - 8-10 млн. пасажирів. За даними Міжнародної асоціації круїзних ліній за 2018 рік, Китай є лідером в круїзному сегменті Азії з 4,24 млн. пасажирами, 70\% усього пасажиропотоку регіону. Активно річкові круїзи почали розвиватися з 1983 року. Основними пасажирами були переважно китайські туристи. Зараз, після завершення будівництва гідровузла «Три ущелини», річка Янцзи привертає все більшу кількість іноземних туристів, в основному пенсіонерів - до 90\%. Щорічно більше 0,5 млн. пасажирів подорожує в круїзах по річці Янцзи.

Основною річковою круїзною лінією в Китаї $\epsilon$ Чунцин - Ічан, відбуваються круїзи по більш довгому маршруту Чунцин - Шанхай, раніше були круїзи Чунцин - Ухань. Виконуються також одноденні круїзи гідровузлом «Три ущелини», навколо Чунцина і Ічана. Річкові круїзи, в класичному їх розумінні, на інших китайських річках не особливо поширені. Більшість круїзів - одноденні або прогулянкові тури на кілька годин і є частиною великих екскурсійних турів. Китай планує розширювати географію річкових круїзів, наприклад, опрацьовується маршрут по річці Перлова від Гонконгу через провінцію Гуандун (місто Гуанчжоу), Учжоу до Гуйган і Наньнін, по річках Фучунь, Цяньтан і Сіньань з Ханчжоу.

Основними круїзними компаніями, які обслуговують «в їзних» туристів на річці Янцзи і оперують РКПС міжнародного рівня, $є$ : «Century Cruises», «Changjiang Cruises», «China Goddess Cruises», «President Cruises», «Victoria Cruises», «Yangtze Gold Cruises», «Sanctuary Yangzi Explorer». В 2019 на річ- ці Янцзи працювало 34 РКПС міжнародного рівня пасажиромісткістю 10406 чоловік, а також 18 РКПС стандартного (для місцевих туристів) рівня пасажиромісткістю 4498 чоловік.

Відсутність низьких мостів і ліній електропередач на ділянці Шанхай - Чунцин дозволяє проектувати і будувати китайські РКПС з надводним габаритом більше за 20 м, що значно перевищує аналогічний параметр на російських і європейських РКПС. 3'являються додаткові палуби і площі, які так необхідні для річкових круїзних суден в умовах обмеженої довжини і ширини.

Зірковість на китайських РКПС призначається відповідно доНаціонального Стандарту GB/T 15731-2015. За фактом, 5* в розумінні Стандарту GB/T 157312015 - це не європейські 5*, тому багато провідних круїзних компаній ще на етапі проектування нових суден і створення дизайн-проекту приділяють особливу увагу світовим тенденціям в річкових круїзах люксового сегменту.

Річкові круїзні судна в Китаї будуються під наглядом інспекційного органу ZC Управління з безпеки мореплавання відповідно до Керівництва про обов'язковий огляд суден внутрішнього плавання. При цьому немає необхідності погоджувати проект і отримувати схвалення CCS. При огляді річкового судна під наглядом ZC призначається район плавання і дозволена ділянка зі швидкими течіями. Для роботи по річці Янцзи від Шанхая до Чунцина потрібна можливість роботи на швидкісних ділянках зі швидкістю течії до 5,0 м/с і район плавання А (розрахункова значна висота хвилі 5\% забезпеченості до 2,0 м), для круїзів між Чунцином і Ічаном - район В (висота хвилі до 1,25 м).

CCS розроблені Правила для внесення в клас круїзних суден додаткових символів. Поширюються вони тільки на морські круїзні і вантажопасажирські судна, але підхід досить сучасний, який узгоджує безпеку, комфортабельність і зірковість круїзів із проектуванням.

\section{REFERENCES}

[1] Egorov A.G. (2020). Razvitiye yevropeyskogo flota i rynka rechnykh kruizov [Development of the European fleet and river cruise market]. Morskoy Vestnik, No. 3 (75), pp. 21-26 (in Russian).

[2] Egorov A.G. (2018). Rechnyye kruiznyye passazhirskiye suda: innovatsionnyye resheniya i ikh primenimost' pri konversii [River cruise passenger ships: innovative solutions and their applicability for conversion]. Odessa: Vestnik ONMU, No. 4 (57), pp. 23-52 (in Russian).

[3] Qiying Zheng. (2015). Crisis Management, Tourism and the Three Gorges Dam, China. PhD Thesis. University of Central Lancashire. - Preston. $-416 \mathrm{p}$.

[4] (2021). Website «MyYangtzeCruise». Retrieved from: http://www.myyangtzecruise.com/development-historyof-three-gorges-cruise-ships_12579_c/ (access date 12.02.2021).

[5] Bernard Aritua, Lu Cheng, Richard van Liere, Harrie de Leijer. (2020). Blue Routes for a New Era: Developing Inland Waterways Transportation in China (International Development in Focus). Edited by the World Bank. - Washington, DC. $-147 \mathrm{p}$.

[6] (2021). Website «China Waterborne Transport Research Institute». Retrieved from: https:/www.wti.ac.cn/ (access date 12.02.2021, in Chinese).

[7] (2021). Website «CEICdata». Retrieved from: https://www.ceicdata.com/en/china/waterway-passenger-traffic (access date 12.02.2021). 
[8] (2020). Website «China government». Statistical Bulletin on the Development of the Transportation Industry in 2019. Retrieved from: http://www.gov.cn/xinwen/2020-05/12/content_5510817.htm (access date 12.02.2021, in Chinese).

[9] (2019). Website «Xinhuanet». Retrieved from: http://www.xinhuanet.com/english/2019-06/16/c_138146520.htm (access date 12.02.2021).

[10] (2021). Website «Yangtze». Retrieved from: https://www.yangtze.com/holiday/3-night-cruise/ (access date 12.02.2021).

[11] (2015). Website «The New York Times». Retrieved from: https://www.nytimes.com/2015/06/03/world/asia/china-cruiseship-capsizing-highlights-yangtze-dangers.html (access date 12.02.2021).

[12] (2021). Website «Century River Cruises». Retrieved from: http://www.centuryrivercruises.com/en/it-cx.html (access date 12.02.2021).

[13] (2021). Website «Into China Travel». Retrieved from: https://www.intochinatravel.com/top-4-river-cruises-in-china/ (access date 12.02.2021).

[14] (2021). Website «China Travel». Retrieved from: https://www.chinatravel.com/guilin-attraction/li-river/ (access date 12.02.2021).

[15] (2020). Website «Sina». Retrieved from: https://finance.sina.com.cn/chanjing/cyxw/2020-08-06/doc-iivhuipn7091649.shtml (access date 12.02.2021, in Chinese).

[16] (2021). Website «Yangtze». Retrieved from: https://www.yangtze.com/cruise-ships/ (access date 12.02.2021).

[17] (2021). Website «News.cn». Retrieved from: http://www.news.cn/ (access date 12.02.2021, in Chinese).

[18] (2015). Website «Sina». Investigation report on the sinking of the Eastern Star passenger ship (full text). Retrieved from: http://news.sina.com.cn/c/2015-12-30/181432681495.shtml (access date 12.02.2021, in Chinese).

[19] (2021). Website «Travel weekly China». Retrieved from: https://www.travelweekly-china.com/73993 (access date 12.02.2021, in Chinese).

[20] (2020). Website «Xinhuanet». Retrieved from: http://www.xinhuanet.com/english/2020-01/23/c_138729558.htm (access date 12.02.2021).

[21] (2020). Website «China Today». Retrieved from: http://www.chinatoday.com.cn/ctenglish/2018/hotspots/kjyq/202002/ t20200222_800194096.html (access date 12.02.2021).

[22] (2021). Website «Travel weekly China». Retrieved from: https://www.travelweekly-china.com/82637 (access date 12.02.2021, in Chinese).

[23] (2020). Website «CATL». Retrieved from: https://www.catl.com/news/681.html (access date 12.02.2021, in Chinese).

[24] (2019). National Standard GB 38030-2019, ICS 47.060. Dimensions series of standard transport ship types passing the locks of inland rivers (in 5 parts). - China (in Chinese).

[25] (2015). National Standard GB/T 15731-2015, ICS 03.200. Star-rating standard for river cruises. - China. - 65 p (in Chinese).

[26] (2019). Rules for Statutory Inspection of Ships and Offshore Equipment - Technical Regulations for Statutory Inspection of Inland Ships: effective from June 1, 2020. Beijing, China: Maritime Safety Administration. - 537 p (in Chinese).

[27] (2020). Rules for Classification of Sea-Going Steel Ships (with 2017, 2018, 2019, 2020 Amendments). Beijing, China: China Classification Society.

[28] (2015). Guidelines for Statutory Surveys of Inland Waterway Ships: effective from July 1, 2015 (in 9 parts). Beijing, China: China Classification Society (in Chinese).

[29] (2021). Website «Falvbangzhu». The difference between ZC and CCS. Retrieved from: https://www.falvbangzhu.com/ zhishi/37486.html (access date 12.02.2021, in Chinese).

[30] (2017). Rules for Cruise Ships: effective from January 1, 2017. Beijing, China: China Classification Society. - 64 p.

[31] (2014). Guide for Passenger Comfort on Ships. Houston, USA: American Bureau of Shipping. - 61 p.

\section{СПИСОК ВИКОРИСТАНОЇ ЛІТЕРАТУРИ}

[1] Егоров А.Г. (2020). Развитие европейского флота и рынка речных круизов. Морской Вестник. № 3(75). С. 21-26.

[2] Егоров А.Г. Речные круизные пассажирские суда: инновационные решения и их применимость при конверсии. Вісник ОНМУ. Одеса : ОНМУ, 2018. Вип. 4(57). С. 23-52.

[3] Qiying Zheng. (2015). Crisis Management, Tourism and the Three Gorges Dam, China. PhD Thesis. University of Central Lancashire. Preston. 416 p.

[4] (2021). Сайт «MyYangtzeCruise». [Електронний ресурс] - Режим доступу: http://www.myyangtzecruise.com/ development-history-of-three-gorges-cruise-ships_12579_c/(дата звернення: 12.02.2021).

[5] Bernard Aritua, Lu Cheng, Richard van Liere, Harrie de Leijer. (2020). Blue Routes for a New Era: Developing Inland Waterways Transportation in China (International Development in Focus). Edited by the World Bank. Washington, DC. 147 p.

[6] (2021). Сайт «Науково-дослідницького інституту водного транспорту KHP». URL : https://www.wti.ac.cn/ (дата звернення: 12.02.2021).

[7] (2021). Сайт «CEICdata». URL : https://www.ceicdata.com/en/china/waterway-passenger-traffic (дата звернення: 12.02.2021).

[8] (2020). Сайт «Уряду КНР». Statistical Bulletin on the Development of the Transportation Industry in 2019. URL : http://www.gov.cn/xinwen/2020-05/12/content 5510817.htm (дата звернення: 12.02.2021). 


\section{СУДНОБУДУВАННЯ №1-2021}

[9] (2019). Сайт «Xinhuanet». URL : http://www.xinhuanet.com/english/2019-06/16/c_138146520.htm (дата звернення: 12.02.2021).

[10] (2021). Сайт «Yangtze». URL : https://www.yangtze.com/holiday/3-night-cruise/ (дата звернення: 12.02.2021).

[11] (2015). Сайт «The New York Times». URL : https://www.nytimes.com/2015/06/03/world/asia/china-cruise-ship-capsizinghighlights-yangtze-dangers.html (дата звернення: 12.02.2021).

[12] (2021). Сайт «Century River Cruises». URL : http://www.centuryrivercruises.com/en/it-cx.html (дата звернення: 12.02.2021).

[13] (2021). Сайт «Into China Travel». URL : https://www.intochinatravel.com/top-4-river-cruises-in-china/ (дата звернення: 12.02.2021).

[14] (2021). Сайт «China Travel». URL : https://www.chinatravel.com/guilin-attraction/li-river/ (дата звернення: 12.02.2021).

[15] (2020). Сайт «Sina». URL : https://finance.sina.com.cn/chanjing/cyxw/2020-08-06/doc-iivhuipn7091649.shtml (дата звернення: 12.02.2021).

[16] (2021). Сайт «Yangtze». URL : https://www.yangtze.com/cruise-ships/ (дата звернення: 12.02.2021).

[17] (2021). Сайт «News.cn». URL : http://www.news.cn/ (дата звернення: 12.02.2021).

[18] (2015). Сайт «Sina». Investigation report on the sinking of the Eastern Star passenger ship (full text). URL: http://news.sina. com.cn/c/2015-12-30/181432681495.shtml (дата звернення: 12.02.2021).

[19] (2021). Сайт «Travel weekly China». URL : https://www.travelweekly-china.com/73993 (дата звернення: 12.02.2021).

[20] (2020). Сайт «Xinhuanet». URL : http://www.xinhuanet.com/english/2020-01/23/c_138729558.htm (дата звернення: 12.02.2021).

[21] (2020). Сайт «China Today». URL : ttp://www.chinatoday.com.cn/ctenglish/2018/hotspots/kjyq/202002/ t20200222_800194096.html (дата звернення: 12.02.2021).

[22] (2021). Сайт «Travel weekly China». URL : https://www.travelweekly-china.com/82637 (дата звернення: 12.02.2021).

[23] (2020). Сайт «CATL». URL : https://www.catl.com/news/681.html (дата звернення: 12.02.2021).

[24] (2019). National Standard GB 38030-2019, ICS 47.060. Dimensions series of standard transport ship types passing the locks of inland rivers (in 5 parts). China.

[25] (2015). National Standard GB/T 15731-2015, ICS 03.200. Star-rating standard for river cruises. China, 2015. 65 p.

[26] (2019). Rules for Statutory Inspection of Ships and Offshore Equipment - Technical Regulations for Statutory Inspection of Inland Ships: effective from June 1, 2020. Beijing, China: Maritime Safety Administration. 537 p.

[27] (2021). Rules for Classification of Sea-Going Steel Ships (with 2017, 2018, 2019, 2020 Amendments). Beijing, China : China Classification Society.

[28] (2015). Guidelines for Statutory Surveys of Inland Waterway Ships: effective from July 1, 2015 (in 9 parts). Beijing, China : China Classification Society.

[29] (2021). Сайт «Falvbangzhu». The difference between ZC and CCS. URL : https://www.falvbangzhu.com/zhishi/37486.html (дата звернення: 12.02.2021).

[30] (2017). Rules for Cruise Ships: effective from January 1, 2017. Beijing, China : China Classification Society. 64 p.

[31] (2014). Guide for Passenger Comfort on Ships. Houston, USA : American Bureau of Shipping. 61 p. 